\title{
PENGARUH MOTIVASI BELAJAR SANTRI TERHADAP PENINGKATAN KAJIAN KITAB SALAF PESANTREN DARUSSALAM BLOKAGUNG TEGALSARI BANYUWANGI TAHUN 2016
}

\author{
M. Khozin Kharis \\ Institut Agama Islam Darussalam (IAIDA) Banyuwangi \\ Email : khozinkharis@gmail.com
}

\begin{abstract}
This research aims to: (1) Knowing the learning motivation of students in improving the study of the book of the salaf in pesantren Darussalam Blokagung Tegalsari Banyuwangi, (2) Determine the study of the book of the salaf in pesantren Darussalam Blokagung Tegalsari Banyuwangi, (3) Determine the influence of learning motivation of students to increase study the book of the salaf in pesantren Darussalam Blokagung Tegalsari Banyuwangi. This research uses descriptive quantitative method with engineering product moment pada test the validity of data and to search for data reliability using the formula alpha, whereas the hypothesis test using $F$ test and $T$, then to test data normality test was used non-parametric tests and data analysis using regression model, Popoulasi this study were boarding school students Darussalam, amounting to 100. After analyzing the data collected, it was found that (1) learning motivation of students is very good. (2) The increase in the book of the Salaf study is very good. (3) There is an effect of learning motivation of students to study the book of the Salaf increase.
\end{abstract}

\section{Keywords: Motivation, Improvement Study Book Salaf}

\begin{abstract}
Abstrak
Penelitian ini bertujuan untuk: (1) Mengetahui motivasi belajar santri dalam peningkatan kajian kitab salaf di pesantren Darussalam Blokagung Tegalsari Banyuwangi, (2) Mengetahui kajian kitab salaf di pesantren Darussalam Blokagung Tegalsari Banyuwangi, (3) Mengetahui pengaruh motivasi belajar santri terhadap peningkatan kajian kitab salaf di pesantren Darussalam Blokagung Tegalsari Banyuwangi. Penelitian ini menggunakan metode deskriptif kuantitatif dengan teknik product momentpada uji validitas data dan untuk mencari reliabilitas data menggunakan rumus alpha, sedangkan pada uji hipotesis menggunakan uji $F$ dan uji $T$, kemudian untuk uji normalitas data menggunakan uji non parametik tes dan analisis data dengan menggunakan model regresi. Popoulasi penelitian ini adalah para santri pondok pesantren Darussalam yang berjumlah 100. Setelah melakukan analisis data yang dikumpulkan, ditemukan bahwa (1) Motivasi belajar santri adalah sangat baik. (2) Peningkatan kajian kitab salaf adalah sangat baik. (3) Ada pengaruh dari motivasi belajar santri terhadap peningkatan kajian kitab salaf.
\end{abstract}

Kata Kunci : Motivasi Belajar, Peningkatan Kajian Kitab Salaf 


\section{A. Latar Belakang}

Sejalan dengan zaman di Era Globalisasi ini kehidupan bermasyarakat berkembang semakin kompleks dan pesat, baik yang menyangkut ilmu pengetahuan dan teknologi maupun kehidupan beragama, maka pendidikan yang sedang berlangsung saat ini makin memperoleh perhatian yang lebih besar dari semua pihak. Hal ini berangkat dari kesadaran bahwa pendidikan adalah upaya untuk membentuk manusia seutuhnya dan jelas membutuhkan waktu yang relatif panjang bahkan berlangsung seumur hidup.

Berbicara mengenai pendidikan di Indonesia, tidak bisa terlepas dari peran dan eksistensi pondok pesantren sebagai lembaga pendidikan tertua di Indonesia. Pondok pesantren merupakan lembaga dan wahana pendidikan agama sekaligus sebagai komunitas santri "ngaji” ilmu agama Islam. Pondok pesantren sebagai lembaga tidak hanya identik dengan makna ke-Islaman, tetapi juga telah membuktikan dirinya sebagai lembaga pendidikan yang memiliki peran besar dalam upaya mencerdaskan kehidupan bangsa.

Pesantren berasal dari kata santri yang diimbuhi awalan pe-dan akhiran -an yang berarti menunjukkan tempat, maka artinya adalah tempat para santri. Adapun sebuah pondok pesantren paling tidak mempunyai beberapa elemen dasar, sebagaimana dikemukakan oleh Zamakhsyari Dhofier (1994:24): "Pondok, masjid, santri, pengajaran kitab-kitab Islam klasik dan kyai merupakan lima elemen dasar dari tradisi pesantren". Ini berarti bahwa suatu lembaga pengajian yang telah berkembang hingga memiliki kelima elemen tersebut, akan berubah statusnya menjadi pesantren.

Kemampuan pesantren untuk tetap survive hingga kini tentu merupakan kebanggaan tersendiri bagi umat Islam, terutama kalangan pesantren. Hal ini sangat beralasan, sebab di tengah derasnya arus era globalisasi, dunia pesantren masih konsisten dengan "kitab kuning" dan konsep sistem pendidikanini yang mungkin oleh sebagian orang dianggap kuno dan konservatif. Padahal, seiring pergeseran zaman di 
Jurnal Darussalam; Jurnal Pendidikan, Komunikasi dan Pemikiran Hukum Islam

Vol. IX, No 1: 198-214. September 2017. ISSN: 1978-4767 (Cetak), ISSN: 2549-4171 (Online)

era globalisasi ini, santri membutuhkan perhatian yang khusus dalam pengkaji kitab salaf, karena sejak dulu pengkajian kitab salaf (kitab kuning) menjadi tolak ukur bagi pondok pesantren, apakah pondok pesantren maju atau tidak, serta berjalan atau tidak.

Berhasil atau tidaknya pendidikan pesantren ini akan dilihat dari bagaimana santri itu membaca dan memahami kitab kuning. justru dengan inilah pondok pesantren Darussalam Blokagung Tegalsari Banyuwangi menyelenggarakan pengajian kita-kitab salaf (kitab kuning). Selain itu, tujuan pondok pesantren Darussalam Blokagung Tegalsari Banyuwangi untuk mencetak santri-santri yang nantinya mampu mendirikan pesantren-pesantren atau madrasah-madrasah dikampungnya maka setidak-tidaknya santri-santri ini nantinya mampu membaca kitab kuning dan menjadi da'i-da'i atau khatib-khatib di masjid.

Begitu pula kitab kuning harus dilestarikan pemakaiannya, karena kitab kuning adalah satu-satunya kitab yang masih murni dan sesuai dengan sumber aslinya, dimana pengarang-pengarang (mualif) kitab-kitab tersebut langsung mengambil dari sumber aslinya sesuai dengan kaidah-kaidah Ushuliyah. Berbicara mengenai pentingnya pengkajian kitab-kitab salaf di era globalisasi, disini guru (ustad) mempunyai peran penting di dalam pengajaranya, apalagi tentang pelajaran agama yang mengkaji kitab-kitab klasik (kitab kuning). Seorang guru/ustadz harus mempunyai pengkajian kitab dengan cara sorogan dan bandongan, kedua teknik ini sangat populer sehingga menjadi ciri khas pesantren. Maka dari sini penulis tertarik untuk meneliti tema ini.

\section{B. Rumusan Masalah}

1. Bagaimana motivasi belajar santri dalam peningkatan kajian kitab salaf di pesantren Darussalam Blokagung Tegalsari BanyuwangiTahun 2016?

2. Bagaimana kajian kitab salaf di pesantren Darussalam Blokagung Tegalsari BanyuwangiTahun 2016?

3. Adakah pengaruh motivasi belajar santri terhadap peningkatan kajian kitab salaf di pesantren Darussalam Blokagung Tegalsari BanyuwangiTahun 2016? 
Jurnal Darussalam; Jurnal Pendidikan, Komunikasi dan Pemikiran Hukum Islam

Vol. IX, No 1: 198-214. September 2017. ISSN: 1978-4767 (Cetak), ISSN: 2549-4171 (Online)

\section{Tujuan Penelitian}

1. Untuk mengetahui motivasi belajar santri dalam peningkatan kajian kitab salaf di pesantren Darussalam Blokagung Tegalsari BanyuwangiTahun 2016

2. Untuk mengetahui kajian kitab salaf di pesantren Darussalam Blokagung Tegalsari BanyuwangiTahun 2016

3. Untuk mengetahui pengaruh motivasi belajar terhadap peningkatan kajian kitab salaf di pesantren Darussalam Blokagung Tegalsari Banyuwangi Tahun 2016

\section{Kajian Pustaka}

1.Pengertian Motivasi Belajar

Menurut Fathurrohman dan Sutikno (2007:19) mengemukakan bahwa "motivasi berpangkal dari kata 'motif', yang dapat diartikan sebagai daya penggerak yang ada di dalam diri seseorang untuk melakukan aktivitas-aktivitas tertentu demi tercapainya suatu tujuan." Adapun menurut Mc Donald dalam Fathurrohman dan Sutikno (2007:19) juga menerangkan bahwa "motivasi adalah perubahan energy dalam diri seseorang yang ditandai dengan munculnya feeling dan didahului dengan tanggapan terhadap adanya tujuan.”

Sedangkan menurut Wahab dalam Rohmalina Wahab (2015:127) mendefinisikan bahwa motivasi (motivation) adalah keseluruhan dorongan, keinginan, kebutuhan, dan daya yang sejenis yang menggerakkan perilaku seseorang. Dalam arti yang luas, motivasi diartikan sebagai pengaruh dari energi dan arahan terhadap perilaku yang meliputi: kebutuhan, minat, sikap, keinginan, dan perangsang (incentives).

Ibrahim dan Nana Syaodih (2003:27) juga mengartikan motivasi merupakan sesuatu tenaga yang berada pada diri individu atau siswa yang mendorongnya untuk berbuat mencapai suatu tujuan". Sejalan dengan pendapatnya Ibrahim dan Nana Syaodih, Winkel yang dikutip oleh Ely Manizar dalam Rohmalina Wahab (2015:127) menyebutkan bahwa motivasi adalahmotif yang sudah menjadi aktif pada saat tertentu, sedang motif adalah daya 
Jurnal Darussalam; Jurnal Pendidikan, Komunikasi dan Pemikiran Hukum Islam

Vol. IX, No 1: 198-214. September 2017. ISSN: 1978-4767 (Cetak), ISSN: 2549-4171 (Online)

penggerak dalam diri seseorang individu untuk melakukan kegiatan tertentu demi mencapai suatu tujuan tertentu.

Dari beberapa pendapat diatas dapat disimpulkan bahwa motivasi merupakan daya penggerak atau pendorong di dalam diri seseorang untuk melakukan sesuatu, sehingga diharapkan dapat mencapai suatu tujuan tertentu.

Menurut Skinner dalam Fathurrohman dan Sutikno (2007:5) mengartikan belajar sebagai suatu proses adaptasi atau penyesuaian tingkah laku yang berlangsung secara progresif. Selain itu, dalam buku yang sama Hilgard dan Bower dalam bukunya Theories of Learning (1975) mengemukakan bahwa belajar berhubungan dengan perubahan tingkah laku seseorang terhadap sesuatu situasi tertentu yang disebabkan oleh pengalamannya yang berulang-ulang dalam situasi itu, dimana peerubahan tingkah laku itu tidak dapat dijelaskan atau dasar kecenderungan respon pembawaan, kematangan atau keadaankeadaan sesaat seorang (misalnya kelelahan, pengaruh obat, dan sebagainya).

Jadi dari kedua pendapat di atas dapat diambil kesimpulan bahwa belajar pada hakekatnya adalah perubahan yang terjadi di dalam diri seseorang setelah melakuka aktivitas tertentu. Sedangkan motivasi belajar menurut Fathurrohman dan Sutikno (2007:19) dapat dikatakan sebagai keseluruhan daya penggerak di dalam diri siswa yang menimbulkan, menjamin kelangsungan dan memberikan arah kegiatan belajar, sehingga diharapkan tujuan yang ada dapat tercapai. Dalam kegiatan belajar, motivasi tentu sangat diperlukan, sebab seseorang yang tidak mempunyai motivasi dalam belajar, tidak akan mungkin melakukan aktifitas belajar.

\section{Jenis-jenis Motivasi Belajar}

Menurut Fathurrohaman dan Sutikno (2007:20) menyebutkan dalam membicarakan jenis-jenis motivasi, dalam hal ini akan dilihat dari dua sudut pandang, yaitu motivasi intrinsik dan motivasi ekstrinsik.

a. Motivasi Intrinsik 
Jurnal Darussalam; Jurnal Pendidikan, Komunikasi dan Pemikiran Hukum Islam

Vol. IX, No 1: 198-214. September 2017. ISSN: 1978-4767 (Cetak), ISSN: 2549-4171 (Online)

Jenis motivasi ini timbul dari dalam diri individu sendiri tanpa ada paksaan dorongan orang lain, tetapi atas dasar kemauan sendiri.

b. Motivasi Ekstrinsik

Jenis motivasi ini timbul sebagai akibat pengaruh dari luar individu, apakah karena adanya ajakan, suruhan, atau paksaan dari orang lain sehingga dengan keadaan demikian siswa mau melakukan sesuatu atau belajar.

3. Fungsi Motivasi Belajar

Oemar Hamalik (2002) dalam Fathurrohman dan Sutikno (2007:20) menyebutkan bahwa ada tiga fungsi motivasi antara lain:

a. Mendorong manusia untuk berbuat, jadi sebagai penggerak atau motor yang melepaskan energi. Motivasi dalam hal ini merupakan langkah penggerak dari setiap kegiatan yang akan dikerjakan

b. Menentukan arah perbuatan yakni kearah tujuan yang hendak dicapai. Dengan demikian motivasi dapat memberikan arah dan kegiatan yang harus dikerjakan sesuai dengan tujuannya.

c. Menyeleksi perbuatan, yakni menentukan perbuatan-perbuatan yang harus dikerjakan yang serasi guna untuk mencapai tujuan, dengan menyisihkan perbuatan-perbuatan yang tidak bermanfaat bagi tujuan tersebut.

Dari beberapa uraian di atas, nampak jelas bahwa motivasi berfungsi sebagai pendorong, pengarah, dan sekaligus sebagai penggerak perilaku seseorang untuk mencapai suatu tujuan. Guru merupakan faktor terpenting untuk mengusahakan terlaksananya fungsi-fungsi tersebut dengan cara dan terutama memenuhi kebutuhan siswa.

4. Faktor-faktor yang Mempengaruhi Motivasi Belajar

Dimyati dan Mudjiono dalam Lutfiana (2013:4) menyebutkan ada beberapa faktor yang mempengaruhi motivasi belajar antara lain:

a. Cita-cita atau aspirasi siswa

Cita-cita akan memperkuat motivasi belajar instrinsik maupun ekstrinsik. Sebab tercapainya suatu cita-cita akan mewujudkan aktualisasi diri. 
Jurnal Darussalam; Jurnal Pendidikan, Komunikasi dan Pemikiran Hukum Islam

Vol. IX, No 1: 198-214. September 2017. ISSN: 1978-4767 (Cetak), ISSN: 2549-4171 (Online)

b. Kemampuan siswa

Keinginan seorang anak perlu dibarengi dengan kemampuan atau kecakapan mencapainya. Kemampuan anak memperkuat motivasi untuk melaksanakan tugas-tugas perkembangan.

c. Kondisi siswa

Kondisi siswa yang meliputi kondisi jasmani dan rohani mempengaruhi motivasi belajar. Seorang siswa yang sakit akan mengganggu perhatian belajarnya disebabkan kondisi yang tidak memungkinkan. Sebaliknya siswa yang sehat akan mudah memusatkan perhatiannya.

d. Kondisi lingkungan siswa

Kondisi lingkungan sekolah yang sehat, aman, tenteram, tertib dan indah akan menimbulkan semangat dan motivasi belajar siswa yang kuat.

e. Unsur-unsur dinamis dalam belajar dan pembelajaran

Siswa memiliki perasaan, perhatian, kemauan, ingatan, dan pikiran yang mengalami perubahan berkat pengalaman hidup. Lingkungan siswa yang berupa lingkungan alam, lingkungan tempat tinggal, dan pergaulan juga mengalami perubahan. Lingkungan budaya seperti, majalah, radio, televise, kesemua lingkungan tersebut mendinamiskan motivasi belajar.

f. Upaya guru dalam membelajarkan siswa

Guru dtuntut untuk berupaya mendidikkan belajar "tata hidup" yang merupakan kerja sama sekolah dan luar sekolah. Dalam hal ini diilusrasikan bahwa pendidikan "tertib hidup" itu meliputi pemeliharaan kebersihan, pemeliharaan fasilitas umum, tertib lalu lintas, tertib pergaulan, dan tertib hidup sebagai umat beragama.

\section{Strategi Menumbuhkan Motivasi}

Menurut Fathurrohman dan Sutikno (2007: 20-21) ada beberapa strategi untuk menumbuhkan motivasi belajar siswa, antara lain:

a. Menjelaskan tujuan belajar kepada peserta didik 
Jurnal Darussalam; Jurnal Pendidikan, Komunikasi dan Pemikiran Hukum Islam

Vol. IX, No 1: 198-214. September 2017. ISSN: 1978-4767 (Cetak), ISSN: 2549-4171 (Online)

Pada permulaan belajar mengajar seharusnya terlebih dahulu seorang guru menjelaskan mengenai tujuan yang akan dicapainya kepada siswa. Makin jelas tujuan maka makin besar pula motivasi dalam melaksanakan kegiatan belajar.

b. Hadiah

Berikan hadiah untuk siswa yang berprestasi. Hal ini akan memacu semangat mereka untuk bisa belajar lebih giat lagi. Di samping itu, siswa yang belum berprestasi akan termotivasi untuk bisa mengejar siswa yang berprestasi.

c. Saingan/kompetensi

Guru berusaha mengadakan persaingan di antara siswanya untuk meningkatkan prestasi belajarnya, dan berusaha memperbaiki hasil prestasi yang telah dicapai sebelumnya.

d. Pujian

Sudah sepantasnya siswa yang berprestasi untuk diberikan penghargaan atau pujian. Tentunya pujian yang bersifat membangun.

e. Hukuman

Hukuman diberikan kepada siswa yang berbuat kesalahan saat proses belajar mengajar. Hukuman ini diberikan kepada siswa dengan harapan agar siswa tersebut mau merubah diri dan berusa memacu mortivasi belajarnya.

f. Membangkitkan dorongan kepada peserta didik untuk belajar Strateginya adalah dengan memberikan perhatian maksimal kepada peserta didik.

g. Membentuk kebiasaan belajar yang baik

h. Membantu kesulitan belajar peserta didik baik secara individual maupun kelompok

i. Menggunakan metode yang bervariasi

j. Menggunakan media yang baik serta harus sesuai dengan tujuan pembelajaran.

6. Definisi tentang Santri 
Jurnal Darussalam; Jurnal Pendidikan, Komunikasi dan Pemikiran Hukum Islam

Vol. IX, No 1: 198-214. September 2017. ISSN: 1978-4767 (Cetak), ISSN: 2549-4171 (Online)

Abdul Ghofur (2009:83) mengemukakan bahwa: "Santri adalah murid dalam pesantren, biasanya tinggal dalam pondok (asrama) dan adakalanya di rumahnya sendiri”. Sedangkan menurut Enung Rukiati dan Fenti Hikmawati (2006:105) "Santri adalah unsur pokok dari suatu pesantren, dan biasanya terdiri dari dua kelompok yaitu: (a) Santri mukim adalah santri yang selama menuntut ilmu tinggal di pondok pesantren, dan (b) Santri kalong adalah santri yang tinggal di luar kompleks pesantren”. Dari pengertian-pengertian tersebut di atas dapat peneliti simpulkan bahwa santri adalah murid-murid yang belajar di pondok pesantren, baik yang menetap di pondok pesantren atau yang berangkat dari rumah masing-masing.

Sementara menurut Imam muhsin, Zuhratul latifah dan Ali sidiqin, (2009: 37) "Ditinjau dari segi domisili, para santri dibedakan menjadi 4 (empat) yaitu:

a. Santri kalong adalah santri yang berasal dari daerah sekitar pondok pesantren dan tidak menetap di pondok (assrama). Santri ini hanya datang ke pondok pesantren pada jam-jam kegiatan belajar mengajar di laksanakan,

b. Santrimukim adalah santri yang berasal dari luar daerah atau luar propinsi. Dan mereka menetap di pesantren selama masa tertentu hingga selesai menjalani program pembelajaran yang dilaksanakan oleh pondok pesantren, atau ada faktor lain yang mengharuskan mereka meninggalkan pondok pesantren.

c. santri kontrak adalah santri yang mengikuti pengajian di pondok pesantren dalam waktu singkat sesuai kesepakatan.

d. santri mingguan adalah santri yang datang ke pondok pesantren seminggu sekali untuk mendengarkan pengajian dan melakukan amalan tarekat yang dibimbing langsung oleh kiyai.

7. Definisi tentang Kitab Salaf

Dalam kitab fathul wahhab, pengertian kitab kuning (kuning) dapat dilihat dalam dua arti, yaitu arti menurut bahasa dan menurut istilah, sebagaimana yang tersebut di bawah ini: 
Jurnal Darussalam; Jurnal Pendidikan, Komunikasi dan Pemikiran Hukum Islam

Vol. IX, No 1: 198-214. September 2017. ISSN: 1978-4767 (Cetak), ISSN: 2549-4171 (Online)

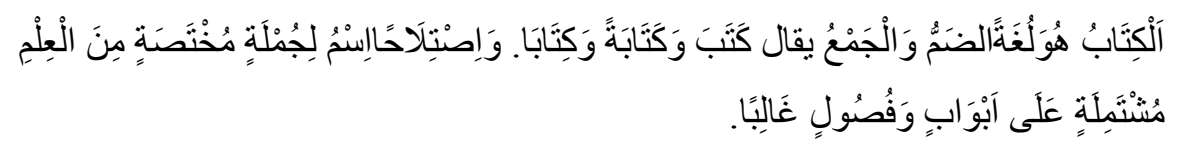

Artinya:

"kitab menurut bahasa artinya menggabungkan dan mengumpulkan, berasal dari fi'il madhi kataba (menulis) dan masdarnya katban, kitabatan, dan kitaba (menulis): dan menurut istilah adalah nama dari suatu ilmutertentu yang biasanya mengandung beberapa bab dan pasal".

Untuk mengetahui pengertian kitab kuning secara lebih jelas, maka dalam penelitian ini penulis akan memaparkan beberapa pengertian kitab kuning menurut para tokoh yang selalu aktif melakukan penelitian untuk memberikan kontribusi terhadap perkembangan Islam, khususnya dalam dunia pesantren, yaitu sebagai berikut:

a. Menurut Masdar F. Mas'udi: "Kitab kuning adalah karya tulis Arab yang ditulis oleh para sarjana Islam sekitar abad pertengahan, dan sering disebut juga dengan Kitab kuno".

b. Menurut Ali Yafie: "Kitab kuning adalah Kitab-kitab yang dipergunakan oleh dunia pesantren yang ditulis dengan huruf Arab dengan bahasa Arab atau Melayu, Jawa, Sunda, dan hurufnya tidak diberi tanda baca (harakat, syakal)".

c. Menurut Martin Van Bruinessen: "Kitab kuning adalah Kitab-kitab klasik yang ditulis berabad-abad yang lalu. Kitab ini disebut di Indonesia sebagai Kitab kuning".

d. KH. MA. Sahal Mahfudh menjelaskan bahwa: "disebut Kitab kuning karena memang kitab-kitab itu dicetak di atas kertas berwarna kuning, meskipun sekarang sudah banyak dicetak ulang pada kertas berwarna putih". 
Jurnal Darussalam; Jurnal Pendidikan, Komunikasi dan Pemikiran Hukum Islam

Vol. IX, No 1: 198-214. September 2017. ISSN: 1978-4767 (Cetak), ISSN: 2549-4171 (Online)

e. Demikian halnya dengan M. Dawam Rahardjo, menurut beliau: "Kitab kuning adalah kitab yang disusun dengan tulisan Arab oleh para sarjana Islam pada abad pertengahan".

Dengan demikian menurut peneliti kitab kuning secara harfiah diartikan sebagai buku atau kitab yang dicetak dengan mempergunakan kertas yang berwarna kuning. Sedangkan menurut pengertian istilah, Kitab kuning adalah kitab atau buku berbahasa Arab yang membahas ilmu pengetahuan agama Islam seperti Fiqih, Ushul Fiqih, Tauhid, Akhlak, Tasawwuf, Tafsir Al-Qur'an dan Ulumul Qur'an, Hadis dan Ulumul Hadis, dan sebagainya yang ditulis oleh Ulama-ulama salaf dan digunakan sebagai bahan pengajaran utama di pondok pesantren.

8. Metode Peningkatan Kualitas Kajian kitab salaf

Dalam meningkatkan kualitas kajian kitab salaf banyak sekali faktor yang harus diperhatikan, namun dalam penulisan ini hanya akan dibahas tentang halhal yang dapat memberikan support dan meningkatkan kualitas kitab salaf kepada para santri di pondok pesantren, yang mana hal-hal tersebut telah menjadi keharusan di lembaga pendidikan seperti halnya di pondok pesantren yang sesuai dengan hukum dan syari'at agama Islam. Dengan adanya tingkat kedisiplinan yang tinggi serta semangat yang berkobar dalam diri setiap anak didik maka akan tercipta suatu keberhasilan dan kualitas pendidikan, sesuai yang tertera dalam kitab Ta'limul Muta'alim. (Aly As Ad, 2007:60)

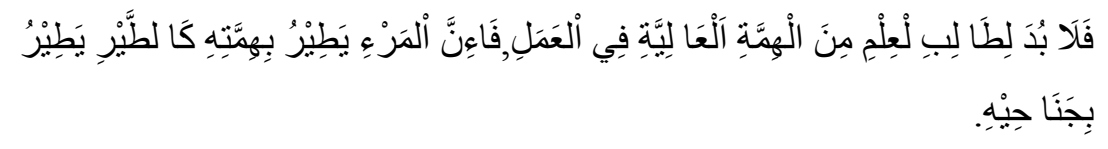

Artinya:

"Menuntut ilmu harus bercita-cita tinggi dalam berilmu, karena manusia akan terbang dengan cita-citanya sebagaimana burung terbang dengan sayapnya”. 
Jurnal Darussalam; Jurnal Pendidikan, Komunikasi dan Pemikiran Hukum Islam

Vol. IX, No 1: 198-214. September 2017. ISSN: 1978-4767 (Cetak), ISSN: 2549-4171 (Online)

Selanjutnya menurut pendapat Abu Thoyyib dalam kitab Ta'lim yang dikutip oleh Aly As Ad (2007: 60):

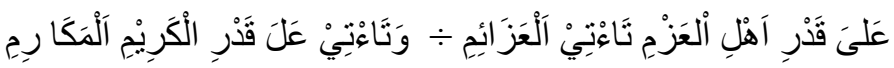

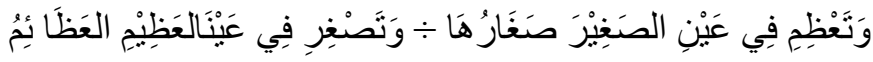

Artinya:

"Cita-cita akan terwujud seukur greget obsesinya, kemuliaan akan terwujud seukur greget cita-cita mulianya, barang kecil tampaknya besar dimata orang yang kecil cita-citanya, barang besar tampaknya kecil dimata orang yang besar cita-citanya".

Berikut ini adalah hal-hal yang dapat meningkatkan kedisiplinan dan support sebagai faktor penunjang dalam rangka meningkatkan kualitas kitab salaf pada santri di pondok pesantren.

a. Ta'zir (Hukuman)

Hery Noer Aly (2008:217) mengemukakan bahwa: Hukuman adalah pemberian stimulus tidak menyenangkan untuk menghilangkan dengan segera tingkah laku pelajar yang mengganggu jalannya kegiatan belajar-mengajar.

Sedangkan hukuman dalam pendidikan Islam ialah sebagai tuntunan dan perbaikan, bukan sebagai hardikan atau balas dendam. Oleh karena itu, juru didik Islam harus mempelajari dulu tabiat dan sifat anak didik sebelum memberi hukuman, bahkan mengajak anak didik untuk turut serta dalam memperbaiki kesalahan yang dilakukannya. Dengan demikian ia akan menyadari kesalahan-kesalahan dan kekeliruankekeliruannya setelah ia turut memperbaiki.

Setelah guru memberi hukuman kepada anak didiknya, guru harus memberi nasehat yaitu upaya menyadarkan pelajar akan pelanggarannya dengan bertolak dari aturan dalam kegiatan belajar-mengajar, serta 
Jurnal Darussalam; Jurnal Pendidikan, Komunikasi dan Pemikiran Hukum Islam

Vol. IX, No 1: 198-214. September 2017. ISSN: 1978-4767 (Cetak), ISSN: 2549-4171 (Online)

kepada pelajar diberi informasi-informasi untuk memperluas wawasannya tentang akibat-akibat dari pelanggarannya.

Suparta (2008:217) mengemukakan bahwa: Prinsip-prinsip yang perlu diperhatikan dalam penggunaan hukuman: sesuai dengan aturan yang berlaku, diberikan dengan segera, dikombinasikan dengan teknik lain, setelah menghukum guru bersikap wajar seperti sebelum menghukum, menghindari hukuman yang justru menjadi penguatan bagi pelajar, serta bervariasi.

Seorang pendidik harus ingat bahwa ada perbedaan antara seorang anak didik dengan anak didik yang lain, baik dari segi tabiat, kesenangan, pembawaan maupun akhlaknya, dan ia harus mengenal setiap muridnya dari dekat agar ia dapat melayani setiap murid dengan layanan yang sesuai. Ada yang cukup ditegur dengan isyarat dan ada yang tidak takut dengan kata-kata. Karena itu, setiap murid itu merupakan suatu persoalan yang berdiri sendiri, yang harus dinilai secara khusus. Suatu hukuman yang cocok bagi seorang anak didik mungkin tidak cocok bagi murid yang lain.

b. Musabaqoh (Lomba)

Salah satu tradisi di pondok pesantren adalah musabaqoh (lomba). Dalam prakteknya tradisi ini sangat menunjang kreativitas dan semangat para santri dalam rangka meraih peringkat yang paling tinggi.

Salah satu jenis lomba yang telah menjadi tradisi pesantren dan juga telah di gelar mulai tingkat kabupaten, propinsi sampai ditingkat nasional adalah Musabaqoh Qiroatul Kutub (MQK).

\section{E. Metode Peelitian}

Jenis Penelitian: deskriptifkuantitatif. Populasi: penelitian ini bersifat penelitian populasi karena subjek kurang dari 100. Teknik Pengumpulan Data: observasi, angket dan dokumentasi. Validitas data menggunakan rumus korelasi 
Jurnal Darussalam; Jurnal Pendidikan, Komunikasi dan Pemikiran Hukum Islam

Vol. IX, No 1: 198-214. September 2017. ISSN: 1978-4767 (Cetak), ISSN: 2549-4171 (Online)

product moment. Reliabilitas data: menggunakan rumus Alpha. Ujinormalitas data: menggunakan rumus Kolmogorof Smirnov. Analisis data: menggunakan rumus regresi linier sederhana

\section{F. Pembahasan}

1. Mengetahui Motivasi Belajar Santri (X) Dalam Peningkatan Kajian Kitab Salaf Pesantren Darussalam Blokagung Tegalsari Banyuwangi Tahun 2016

Sesuai dengan apa yang diuraikan pada bagian sebelumnya bahwa permasalahan yang dipertanyakan dalam penelitian ini adalah Adakah pengaruh Motivasi belajar terhadap peningkatan kajian kitab salaf di Pesantren Darussalam Blokagung Tegalsari Banyuwangi Tahun 2016. Hasil penelitian ini menunjukkan bahwa nilai koefisien regresi variabel motivasi belajar $(\mathrm{X})$ adalah sebesar 0,671. Hal ini berarti bahwa pengaruh motivasi belajar (X) mempunyai pengaruh nilai $67,1 \%$ terhadap pengaruh peningkatan kajian kitab salaf.

2. Mengetahui Kajian Kitab Salaf (Y) Di Pesantren Darussalam Blokagung Tegalsari Banyuwangi Tahun 2016

Dengan demikian hasil penelitian ini juga menunjukkan bahwa apabila santri memiliki motivasi belajar (X) yang baik maka peningkatan kajian kitab salaf (Y) juga akan semakin baik di Pesantren Darussalam Blokagung Tegalsari Banyuwangi Tahun 2016. Dengan persamaan regresi $\mathrm{Y}=19,694+0,671 \mathrm{X}$ apabila diukur dengan instrumen yang sama yang digunakan dalam penelitian ini, maka setiap perubahan variabel motivasi belajar $(\mathrm{X})$ sebesar satu satuan dapat diperkirakan peningkatan kajian kitab salaf (Y) akan berubah 19,694 pada arah yang sama.

3. Pengaruh Motivasi Belajar Santri (X) Terhadap Peningkatan Kajian Kitab Salaf (Y) Pesantren Darussalam Blokagung Tegalsari Banyuwangi Tahun 2016

Permasalahan yang ingin dijawab dalam penelitian ini adalah pengaruh variabel motivasi belajar (X) terhadap peningkatan kajian kitab salaf (Y) di Pesantren Darussalam Blokagung Tegalsari Banyuwangi Tahun 2016. Hasil penelitian 
Jurnal Darussalam; Jurnal Pendidikan, Komunikasi dan Pemikiran Hukum Islam

Vol. IX, No 1: 198-214. September 2017. ISSN: 1978-4767 (Cetak), ISSN: 2549-4171 (Online)

menunjukkan bahwa pengaruh motivasi belajar $(\mathrm{X})$ mempunyai pengaruh yang besar terhadap peningkatan kajian kitab salaf yaitu sebesar 67,1\%.

\section{G. Kesimpulan}

Berdasarkan hasil penelitian dan analisis data sebagaimana diuraikan pada bab sebelumnya, dapat disimpulkan sebagai berikut:

1. Berdasarkan uji t diperoleh hasil hitung variabel motivasibelajarsantri (X) di Pesantren Darussalam BlokagungTegalsariBanyuwangiTahun 2016 sebesar 10,885 dengan taraf signifikansi $0,000<0,05$ yang berarti motivasibelajarsantrisangat baik

2. Berdasarkan uji t diperoleh hasil hitung variabel peningkatan kajian kitab salaf (Y) di Pesantren Darussalam Blokagung Tegalsari Banyuwangi Tahun 2016 sebesar 4,558 dengan taraf signifikansi $0,000<0,05$ yang berarti peningkatan kajian kitab salaf sangat baik

3. Berdasarkan penghitungan yang dilakukan dengan menggunakan rumus regresi sederhana $t$ hitung diperoleh 4,558> 0,195 dengan taraf signifikansi 0,000 $<0,05$ yang berarti diperoleh pengaruh yang signifikan dengan koefisien regresi sebesar 0,671 yang dipersenkan menjadi 67,1\%. Jadi ada pengaruh motivasi belajar (X) terhadap peningkatan kajian kitab salaf (Y) di Pesantren Darussalam Blokagung Tegalsari Banyuwangi Tahun 2016 sebesar 67,1\%.

\section{H.Saran}

Setelah mengetahui ada pengaruh motivasi belajar terhadap peningkatan kajian kitab salaf di Pesantren Darusssalam Blokagung Tegalsari Banyuwangi Tahun 2016, maka perlu kami sampaikan saran-saran sebagi berikut:

1. Motivasi belajar santri di Pesantren Darussalam Blokagung Tegalsari Banyuwangi sudah sangat baik akan tetapi harus lebih ditingkatkanl agi

2. Peningkatan kajian kitab salaf di Pesantren Darussalam Blokagung Tegalsari Banyuwangi sudah sangat baik akan tetapi perlu lebih ditingkatkan lagi, Sebab 
Jurnal Darussalam; Jurnal Pendidikan, Komunikasi dan Pemikiran Hukum Islam

Vol. IX, No 1: 198-214. September 2017. ISSN: 1978-4767 (Cetak), ISSN: 2549-4171 (Online)

di Zaman Era Globalisasi ini yang semakin banyak tantangan yang harus dihadapi oleh para santri

3. Seorang kyi dan para ustad haru selalu memberi motivasi kepada para santri untuk lebih giat lagi mengkaji kitab salaf, sebab motivasi itu mempunyai pengaruh terhadap para santri untuk lebih meningkatkan lagi dalam mengkaji kitab salaf di Pesantren Darussalam Blokagung Tegalsari Banyuwangi

\section{Daftar Putaka}

Abuddin Nata. 2001. Pemikiran Para Tokoh Pendidikan Islam. Jakarta: PT. Raja Grafindo Persada.

Anton M. Moeliono. 1990. Kamus Besar Bahasa Indonesia. Jakarta: Depdikbud Balai Pustaka.

Arikunto,S. 1990. Metode Penelitian. Jakarta: Penerbit Kangasa.

Arikunto, S. 2002. Prosedur Penelitian, Suatu Pendekatan Praktek. Jakarta: PT. RinekaCipta.

As Ad Aly. 2007. Terjemah Ta'limul Muta'alim. Yogyakarta: Menara Kudus.

Enung K. Rukiati, Fenti Hikmawati. 2006. Sejarah Pendidikan Islam Di Indonesia Bandung: PustakaSetia.

Dhofier, Zamakhsyari.1994. Tradisi Pesantren. Jakarta: LP3ES.

Dimyati Dan Mudjiono. 2013. Belajar Dan Pembelajaran. Jakarta: PT RinekaCipta.

Fathurrohman, Pupuh Dan Sutikno, M. Sobry. 2007. Strategi Belajar Mengajar. Bandung: Refika Aditama.

Faisal S. 1995. Format-Format Penelitian Sosial, Dasar-Dasar Dan Aplikasi. Cetakan Ketiga. Jakarta: PT. Raja Grofido Persada.

Ghofur Abdul. 2009. Model Pengembangan Pendidikan Pesantren Bagi Anak Pengungsi. Malang: Aditya Media.

Hamalik, Oemar. 2001. Proses Belajar Mengajar. Jakarta: BumiAksara.

Ibrahim Dan Syaodih S. Nana. 2003. Perencanaan Pengajaran. Jakarta: PT Rineka Cipta.

Margono, Drs. S. Margono. 2004. Metodologi Penelitian Pendidikan. Jakarta: Rineka Cipta.

Marzuki. 2000. Metodologi Riset. Yogyakarta: BP + E-UII.

Muhibbin Syah. 2008. Psikologi Pendidikan Dengan Pendekatan Baru. Bandung: PT Remaja Rosda Karya.

Nasution. 2003. Metode Research. Jakarta: PT. Bumi Aksara.

Nor Aly Herry Dan Suparta. 2008. Metodologi Pengajaran Agama Islam. Jakarta: Amissco.

PS, Djarwanto. 1984. Pokok-Pokok Analisa Laporan Keuangan. Yogyakarta.

Siyaqi.Http: Karya Ilmiah.Um. Ac. Id/Index. Pht/Disertasi/Article/View. 901. (Online). 
Jurnal Darussalam; Jurnal Pendidikan, Komunikasi dan Pemikiran Hukum Islam

Vol. IX, No 1: 198-214. September 2017. ISSN: 1978-4767 (Cetak), ISSN: 2549-4171 (Online)

Soepono, Prasetyo. 1993. Analisis Shift-Share: Perkembangan Dan Penerapan. Jurnal Ekonomi Dan Bisnis Indonesia.

Sugiyono. 2009. Metode Penelitian Bisnis (Pendekatan Kuantitatif, Kualitatif, R\&D) Bandung: Alfabeta.

T. Rika Joni. 1977. Teori Mengajar Dan Psikologi Belajar. Jakarta: Kencana Prenada Media Group.

Wahab, Rohmalina. 2015. Psikologi Belajar. Jakarta: PT. Raja Grafindo Persada.

Walker, Adward L. 1973. Condisioning And Instrumental Learning. (Ahli Bahasa: Tim Dosen Fakultas Psikologi Universitas Indonesia). Jakarta: Yayasan Penerbit UI. 